\title{
POLEMIK KEBIJAKAN TRANSPORTASI ONLINE
}

\author{
Agnes Cellyana Nainggolan ${ }^{1}$, Imam Sopwan ${ }^{1}$, Nurul Auliah ${ }^{1}$, \\ Ni'matullah $^{1}$, Adien Hasanuddin ${ }^{1}$ \\ 1Jurusan Magister Administrasi Publik, Universitas Sultan Ageng Tirtayasa \\ Jl. Raya Jakarta KM 4, Panancangan, Kec. Cipocok Jaya, Kota Serang, Banten 42124
}

\begin{abstract}
Nowadays, online transportation become a public needs, especially for people who live in some big cities. But this phenomena doesn't come with any public policy about online transportation. There is still a contradictory among public policies about transportation that makes the companies of online transportation formulate their own policies which provokes conflicts. Methods used for this research is qualitative-descriptive methods. Researchers tried to explain phenomena and polemic happened by the lack of clear policy of online transportation.
\end{abstract}

Keywords: Public Policy, Online Transportation, Public Service

\section{Pendahuluan}

Transportasi di Indonesia sangatlah krusial, baik itu transportasi pribadi, transportasi umum maupun transportasi online yang kini sedang marak digunakan. Jalanan penuh dengan kendaraan, utamanya kendaraan pribadi.

Kini transportasi online diyakini membantu masyarakat dalam memfasilitasi mobilitas mereka. Transportasi online diapresiasi dengan baik oleh masyarakat. Namun sangat disayangkan belum ada kebijakan yang mengatur moda transportasi online dengan jelas, baik dari segi pengguna maupun pengendara. kehadiran trasnportasi on line yang pada hakikatnya melanggar peraturan perundang-undangan di bidang Lalu Lintas Angkutan Jalan
(LLAJ), tepatnya yaitu UndangUndang Nomor 14 Tahun 2009 Tentang Lalu Lintas Angkutan Jalan (LLAJ) (Perhubungan, 2009) di mana kehadiran transportasi online dianggap menimbulkan ketidakadilan bagi transportasi umum sejenis yang tidak berbasis online, sedangkan penegakan hukumnya masih lemah. Kehadiran transportasi online berpengaruh pada turunnya pendapatan taksi konvensional dan angkutan umum lainnya sebesar $70 \%$.

Meskipun dari segi hukum transportasi online dianggap melanggar UU, tetapi kebutuhan masyarakat terhadap transportasi online menjadikan tidak adanya tindakan hukum yang kuat bagi pelanggaran tersebut. Heru Sutadi kepada The Daily Octagon (2015) 
mengungkapkan bahwa masyarakat masih malas berjalan kaki, sehingga transportasi online menjadi pilihan karena bisa langsung sampai ke depan rumah. "Agak malas jalan kaki sedikit saja. Kalau naik angkot, maunya turun pas pintu pagar rumah atau ujung jalan rumah . terlewat sedikit langsung marah-marah," ujarnya. Ia juga menyatakan bahwa teknologi membuka peluang integrasi terhadap transportasi, sehingga muncullah transportasi online. Ia pun berharap hal-hal seperti privasi dan kenyamanan pengguna juga ditingkatkan, karena banyak kasus di mana pengguna diteror karena memberi review buruk, penumpang dirayu karena cantik dan karena nomor teleponnya diketahui pengendara. Untuk permasalahanpermasalahan berikut, Pemerintah diharapkan mendapatkan titik temu agar tidak ada pihak manapun yang dirugikan, juga ada kepastian hukum bagi pengendara dan pengguna. Namun hingga kini Pemerintah belum juga membuat kebijakan terkait transportasi online.

Jurnal ini akan membahas tentang bagaimana hambatan yang terjadi karena tidak adanya kebijakan yang mengatur transportasi online.

\section{Metode Penelitian}

Metode Penelitian dan pemilihan informan Penelitian ini menggunakan metode kualitatif (qualitative method) yaitu sebuah metode yang menurut Creswell (Creswell, 2012) sebagai usaha untuk membangun makna suatu fenomena berdasarkan pandangan-pandangan dari partisipan. Lebih lanjut lagi Strauss dan Corbin (Strauss \& Corbin, 2007) menyatakan bahwa penelitian kualitatif sebagai jenis penelitian yang temuan-temuannya tidak diperoleh dari prosedur statistik atau bentuk hitungan lainnya. Dengan kata lain, peneliti akan bekerja dengan data yang berupa deskripsi. Contohnya dapat berupa penelitian tentang kehidupan, riwayat, perilaku seseorang, disamping juga tentang peranan organisasi, pergerakan sosial atau hubungan timbal balik. Sedangkan pendekatan yang digunakan adalah dengan metode naratif. Metode kualitatif dipilih karena sesuai dengan tujuan penelitian ini, peneliti bermaksud menggambarkan dan menjelaskan bukan mencari hubungan antarvariabel. Dengan demikian, tidak seperti pada penelitian kuantitatif, keterwakilan (representativeness) bukanlah keharusan karena penelitian ini tidak dimaksudkan untuk membuat generalisasi. Hal yang harus diperhatikan dalam penelitian kualitatif adalah konsistensi dan validitas data atau informasi. Oleh karena itu, peneliti harus menggunakan strategi yang dikenal sebagai triangulasi.

\section{Analisis Dan Pembahasan}

Transportasi merupakan sarana publik yang digunakan oleh masyarakat secara bersama-sama, sehingga harus ada regulasi yang 
diciptakan guna menghindari konflik antar kelompok masyarakat.

Thomas R. Dye (Nugroho, 2016) mengungkapkan bahwa "kebijakan publik adalah apa yang dikerjakan pemerintah dan yang tidak dikerjakan oleh pemerintah".

Hoogerwerf (Ali \& Alam, 2012) menyatakan bahwa tujuan Pemerintah dalam menciptakan kebijakan adalah sebagai berikut:

1. Memelihara ketertiban umum (negara sebagai stabilisator);

2. Melancarkan perkembangan masyarakat dalam berbagai hal (negara sebagai koordinator);

3. Memperuntukkan dan membagi berbagai materi (negara sebagai pembagi alokasi).

Dari pendapat Hoogerwerf tersebut jelas disebutkan bahwa negara mempunyai tujuan-tujuan yang jelas dan berorientasi pada kepentingan rakyat. Peran-peran pemerintah sangat memiliki pengaruh besar bagi stabilitas bangsa.

Adapun House

(Nugroho, 2016) menyatakan pilihan melakukan evaluasi kebijakan dapat menggunakan "goal free model", yaitu model tujuan bebas. Dengan indikator utama adalah "pilihan pengguna dan manfaat sosial". Model ini dirasa tepat untuk digunakan dalam memecahkan permasalahan transportasi online karena adanya keterlibatan pada target group. Maulamin dan Istianto (Maulamin \& Istianto, 2018) mengutip contoh target group yang digunakan dalam diskusi tentang kebijakan adalah pengendara transportasi seperti sopir taksi online dan taksi konvensional, pemilik kendaraan yang digunakan taksi online, pengelola aplikasi telepon selular, sopir angkutan umum lainnya serta pengguna jasa transportasi online. Terjadinya penolakan terhadap isi kebijakan dalam teori disebut problem government yaitu perbedaan persepsi dan definisi mengenai isi kebijakan. Sedangkan action government yaitu melakukan komunikasi, lobby, negosiasi dan kompromi dengan target group. Jika pada tahap formulasi kebijakan seluruh proses tersebut sudah clear maka jika terjadi penolakan terhadap isi kebijakan akan dapat dieliminir atau kemungkinan penolakan terhadap implementasi sudah berkurang atau "zero conflict". Apabila pada tahap formulasi kebijakan belum clear dengan target groupnya, dapat diduga masih ada masalah sehingga pada proses implementasi kebijakannya bisa mengalami kegagalan.

Menurut Van Meter Van Horn (Agustino, 2012) menyatakan, "implementasi kebijakan adalah tindakan-tindakan yang dilakukan oleh individu-individu (dan kelompok) pemerintah dan swasta yang diarahkan pada pencapaian tujuan dan sasaran yang telah ditetapkan"

Implementasi kebijakan pada prinsipnya adalah cara agar sebuah kebijakan dapat mencapai tujuannya, tidak lebih dan tidak kurang, untuk mengimplementasikan kebijakan publik ada dua pilihan langkah yaitu, 
langsung mengimplementasikan dalam bentuk program atau melalui formulasi kebijakan derivate atau turunan dari kebijakan publik tersebut.

Menurut William N Dunn (Dunn, 1999) istilah evaluasi dapat disamakan dengan penaksiran (appraisal), pemberian angka (rating) dan penilaian (assesment). Evaluasi memberi informasi yang valid dan dapat dipercaya mengenai kinerja kebijakan, yaitu seberapa jauh kebutuhan, nilai dan kesempatan telah dapat dicapai melalui tindakan publik; evaluasi memberi sumbangan pada klarifikasi dan kritik terhadap nilai-nilai yang mendasari pemilihan tujuan dan target; dan evaluasi memberikan sumbangan pada aplikasi metode-metode analisis kebijakan lainnya, termasuk perumusan masalah dan rekomendasi.

Secara umum, William N Dunn menggambarkan kriteria-kriteria evaluasi kebijakan publik sebagai berikut: 1) Efektivitas (apakah hasil yang diinginkan telah tercapai?); 2) Efesiensi (seberapa banyak usaha diperlukan untuk mencapai hasil yang diinginkan?); 3) Kecukupan (seberapa jauh pencapaian hasil yang diinginkan memecahkan masalah?); 4) Perataan (apakah biaya manfaat didistribusikan dengan merata kepada kelompok-kelompok yang berbeda?); 5) Responsivitas (apakah hasil kebijakan memuaskan kebutuhan, preferensi, atau nilai kelompok-kelompok tertentu?); 6) Ketepatan (Pertanyaan: apakah hasil (tujuan) yang diinginkan benar-benar berguna atau bernilai?).

Teori-teori di atas menjadi pisau bedah bagi penelitian ini. Merujuk kepada teori evaluasi kebijakan, penulis akan melihat kebijakan-kebijakan yang sudah dibuat terlebih dahulu oleh pemerintah Indonesia. Pun akan dipahami apakah kebijakan-kebijakan tersebut relevan dengan fenomena yang terjadi terkait transportasi online di Indonesia? Apakah sudah tepat dan sudah mencapai hasil yang diinginkan? Penelitian ini ditulis untuk membahas kebijakankebijakan tentang transportasi online di Indonesia, sampai sejauh mana kebijakan tersebut mampu menyelesaikan masalah-masalah yang ada di Indonesia.

Pada tahun 2017, Yayasan Lembaga Konsumen Indonesia (YLKI) mengeluarkan data primer mengenai persepsi komitmen transportasi umum tentang kebijakan pemerintah. Tahun 2016 dilakukan penelitian tahap pertama, di mana masyarakat melancarkan penolakan terhadap kebijakan pemerintah yaitu Permenhub nomor 32 tahun 2016. Setelah dilakukan revisi kemudian terbit Permenhub 26 tahun 2017. Kebijakan ini masih ditolak dan bahkan terjadi demo besar-besaran di daerah- daerah. Pada saat demonstrasi sudah mulai mereda, pada bulan November 2017 lanjut penelitian untuk melengkapi survey tentang peraturan di atas, dan diteruskan melalui Indept Interview terhadap beberapa reponden terpilih 
sebagai informan yaitu para sopir online, taksi konvensional angkutan umum, pengguna dan policy maker di Pemerintahan.

\section{Permasalahan Kebijakan Tarif Transportasi Online yang Ditentukan Oleh Pemerintah}

Hasil survey Yayasan Lembaga Konsumen Indonesia (YLKI) tahun 2017 terhadap 4.668 responden sebagaimana disusun dalam tabeltabel di bawah.

Alasan Menggunakan Transportasi Online

\begin{tabular}{|l|l|r|}
\hline No. & $\begin{array}{l}\text { Alasan } \\
\text { Menggunakan }\end{array}$ & Persentase \\
\hline 1 & Murah & $84,1 \%$ \\
\hline 2 & Cepat & $81,9 \%$ \\
\hline 3 & Nyaman & $78,8 \%$ \\
\hline 4 & Aman & $61,4 \%$ \\
\hline
\end{tabular}

Sumber : YLKI, 2017

Tabel di atas menunjukkan bahwa alasan masyarakat memilih menggunakan transportasi online adalah karena alasan murah (84\%). Artinya bahwa masyarakat Indonesia mengharapkan bahwa transportasi sebagai kebutuhan dasar menjadi kewajiban pemerintah dalam menentukan tarif yang rendah.

Kemudian YLKI melakukan survey atas moda transportasi online yang menjadi pilihan masyarakat.

Moda Transportasi Online yang Digunakan Masyarakat

\begin{tabular}{|l|l|l|}
\hline No & $\begin{array}{l}\text { Moda yang } \\
\text { digunakan }\end{array}$ & Persentase \\
\hline 1 & Mobil dan Motor & $55 \%$ \\
\hline
\end{tabular}

\begin{tabular}{|l|l|l|}
\hline 2 & Motor Saja & $21 \%$ \\
\hline 3 & Mobil Saja & $24 \%$ \\
\hline
\end{tabular}

Sumber: YLKI, 2017

Tabel di atas menunjukkan bahwa masyarakat membutuhkan moda transportasi mobil yang dapat memuat penumpang lebih banyak. Akan tetapi sepeda motor juga menjadi pilihan yang digunakan sebagai alat mobilitas kegiatan sehari hari (55\%). Artinya ketika kondisi transportasi umum di kota belum mampu memberikan pelayanan publik yang memuaskan maka sepeda motor pun dipakai sebagai angkutan umum. Kemudian YLKI mencoba melihat dari sisi kebijakan transportasi online.

\section{Kebijakan Transportasi Online}

\begin{tabular}{|l|l|r|}
\hline No & $\begin{array}{l}\text { Sikap } \\
\text { Responden }\end{array}$ & Persentase \\
\hline 1 & Tidak Setuju & $62,8 \%$ \\
\hline 2 & Setuju & $37,2 \%$ \\
\hline
\end{tabular}

Sumber: YLKI, 2017

Dalam tabel di atas, ketika ditanyakan keterkaitannya dengan kebijakan tentang transportasi online maka yang memberikan jawaban "tidak setuju" adalah sebanyak 62,8\%. Artinya bahwa jika respodennya adalah masyarakat pengguna transportasi online, maka mereka khawatir kemunculan kebijakan tersebut akan mengakibatkan trasnportasi online dilarang oleh pemerintah. Di Indonesia, transportasi online adalah kebutuhan mendasar bagi masyarakat di Kota-kota besar seperti Jakarta, Bandung dan Surabaya. Sebanyak 84\% responden 
memilih sarana transportasi online dikarenakan harganya yang murah.

Namun meskipun sebagian besar masyarakat merasa puas atas pelayanan publik transportasi online yang mencapai 77\%, pemerintah wajib melakukan "pengawasan" yang ketat atau terus menerus terhadap beroperasinya transportasi online agar masyarakat tidak dirugikan. Masyarakat pengguna yang disurvey oleh YLKI juga sebanyak $67 \%$ menyatakan tidak setuju terhadap kebijakan pemerintah. Masyarakat berharap adanya peraturan yang membuat pemanfaatan transportasi online lebih tertib dan aman. Karena masyarakat menyatakan tidak melakukan komplain sebesar 84\%, berarti kepuasan pelanggan transportasi online sangat tinggi.

Pemerintah diharapkan mampu menjaga keseimbangan antara dua pihak, yaitu pengusaha dan pengguna. Hal ini dikarenakan banyaknya konflik sosial yang terjadi diakibatkan oleh tidak adanya kebijakan yang jelas bagi sarana transportasi online. Suatu kebijakan pada hakikatnya dibuat dan dilaksanakan untuk menyelesaikan masalah (problem solving).

Muhammad Sufyan

Abdurrahman dalam inet.detik.com (14/10/2017) menyatakan bahwa: "transportasi konvensional setidaknya sudah memiliki mandatori awal sebelum beroperasi setidaknya 11 poin kewajiban yakni jenis angkutan sewa, kapasitas silinder mesin kendaraan, batas tarif angkutan sewa khusus, kuota jumlah angkutan sewa khusus, kewajiban STNK berbadan hukum, pengujian berkala/KIR, pajak, akses digital dashboard, dan sanksi. Seluruhnya jelas butuh biaya, namun ada kepastian hukum tegas dan jelas di sana. Di sisi lain, transportasi online hadir menegasikan itu semua namun gerak gerik, motif, dan operasional sepenuhnya bisnis dan profit. Sama saja dengan transportasi konvensional namun cenderung mengakali, bahkan kalau bisa lolos dari itu semua, sehingga pebisnis (sekalipun jaringan global) bergerak niraturan."

Ia juga mengungkapkan bahwa Ketika gejolak awal utama di tanah air mulai muncul, yang antara lain ditandai rusuh demo taksi konvensional ke DPR per 22 Maret 2016 lalu, maka regulator berwenang, dalam hal ini Kementerian Perhubungan, baru bergerak lebih konkrit setelah sebelumnya cenderung tidak mengatur potensi masalah tersebut secara ketat. Maka, lahirlah Permenhub 32/2016 tentang Penyelenggaraan Angkutan Orang tidak Dalam Proyek yang sekalipun relatif terlambat, namun spiritnya bagus karena ada 18 bleid yang kemudian memberikan perlakuan kesetaraan antara pelaku transportasi konvensional dengan transportasi dalam jaringan. Situasi ini sebaiknya mengingatkan kita soal harmonisasi angkutan umum dengan taksi saat awal-awal beroperasi puluhan tahun silam. Kala itu, kondisi relatif harmonis karena sopir angkutan umum melihat taksi juga sama gunakan plat kuning, uji KIR 
tiap tahun, bayar pajak komersial, SIM harus umum, dan aneka perlakuan kesetaraan lainnnya.

Efektivitas

Permenhub

sebenarnya sudah mulai jalan, ketika sejumlah pelaku tranportasi daring di Bandung khususnya dan Jabar umumnya kemudian mau berhimpun membuat koperasi guna memenuhi aturan Permenhub tadi. Mereka menyadari sebagai pengusaha, tentu ada perlakuan aturan yang mengiringi, tak bisa terus mengakali regulasi. Namun situasi yang menjurus harmonis ini kemudian buyar ketika Mahkamah Agung pertengahan September 2016 lalu membatalkan 14 dari 18 bleid Permenhub No 32/2016 dengan esensinya menciptkan kembali ketimpangan perlakukan seperti tidak perlu adanya pengaturan tarif hingga uji KIR.

Dilansir dalam liputan6.com (11/04/2018), Tulus Abadi, ketua harian YLKI dalam Forum Group Discussion (FDG) Komite Ekonomi dan Industri Nasional menyatakan dari 4.600 responden, 40 persen kecewa dengan pelayanan transportasi online. Selain soal layanan, yang menjadi persoalan selanjutnya adalah masalah penggunaan motor dan mobil pribadi sebagai transportasi umum. Sebagai contoh, dalam Undang-Undang (UU) Nomor 22 Tahun 2009 tentang Lalu Lintas dan Angkutan Jalan (LLAJ), sepeda motor sebenarnya tidak memenuhi syarat untuk digunakan sebagai transportasi umum. "Ini perdebatan apakah masuk transportasi umum atau tidak. Karena dalam UU dua kendaraan ini tidak masuk dalam angkutan umum."

Belakangan muncul masalah penetapan tarif untuk ojek online oleh Kementerian Perhubungan (Kemenhub). Menurut Tulus, sepeda motor tidak masuk dalam transportasi umum, maka pemerintah tidak bisa mengintervensi soal tarif. "Jadi kalau mau intervensi pada tarif ini harus dibereskan dulu (aturannya). Jadi diserahkan saja pada pemainnya, yang penting tidak melanggar UU Persaingan Usaha. Tarif silakan tentukan sendiri," ujarnya.

Masalah ini tentunya menjadi dilema bagi perusahaan transportasi online dalam beroperasi, sehingga perusahaan transportasi online akhirnya menentukan tarif mereka sendiri dan pemerintah tidak bisa mengintervensi soal tarif.

\section{Kesimpulan}

Tidak adanya kebijakan yang mengatur transportasi online dengan baik membuat bisnis transportasi online seolah-olah berjalan tanpa pegangan. Hal ini memicu mereka untuk memberlakukan kebijakannya sendiri yang kemudian tidak jarang menimbulkan konflik. Secara substansi, perusahaan transportasi online tidak sepenuhnya salah, mengingat harus ada peraturan yang jelas demi berjalannya perusahaan transportasi online. Kedepannya penulis berharap agar pemerintah dapat segera merumuskan kebijakan tentang perusahaan transportasi online agar tidak terjadi konflik sosial 
dan tidak ada lagi pihak yang merasa dirugikan.

\section{Referensi}

Agustino, L. (2012). Dasar-dasar Kebijakan Publik.

Ali, F., \& Alam, A. S. (2012). Studi Kebijakan Pemerintah.

Creswell, J. W. (2012). Research Design.

Dunn, W. N. (1999). PengantarAnalisis-Kebijakan-Publik.

Maulamin, T., \& Istianto, B. (2018). Jurnal Kebijakan Transportasi Online dan Konflik Sosial.

Nugroho, R. (2016). Kebijakan Publik di Indonesia.

Perhubungan, M. (2009). UU 14 Tahun 2009, (1).

Strauss, A., \& Corbin, J. (2007). Dasardasar Penelitian Kualitatif.

Peraturan Menteri Perhubungan Nomor 32 Tahun 2106 Tentang Penyelenggaraan Angkutan Orang Dengan Kendaraan Bermotor Umum Tidak Dalam Trayek

Peraturan Menteri Perhubungan Nomor 26 Tahun 2017 Tentang Penyelenggaraan Angkutan Orang Dengan Kendaraan Bermotor Umum Tidak Dalam Trayek

Yayasan Lembaga Konsumen Indonesia (YLKI), Hasil Survey Transportasi Online (2017) https://ylki.or.id/2017/07/wart a-konsumen-transportasionline-kawan-atau-lawan/
Undang Undang Lalu Lintas Angkutan Jalan Nomor 22 Tahun 2009

Detik.com. "Mencari Solusi Bersama Kisruh Transportasi Online." https://inet.detik.com/cyberlif e/d-3683667/mencari-solusibersama-kisruh-transportasionline. 5 Desember 2019

The Daily Oktagon. "Bagaimana Perkembangan Transportasi Online Menurut Pakar?" https://daily.oktagon.co.id/bag aimana-perkembangantransportasi-online-menurutpakar/. 5 Desember 2019

Kompasiana.com. "Mengapa Ada Konflik Antara Transportasi Online dan Konvensional?" https://www.kompasiana.com /thsalengke/58d08ff56ea8344 c048b4567/mengapa-adakonflik-antara-transportasionline-dan-konvensional. Desember 2019. 